\title{
Impaired delayed hypersensitivity in juvenile rheumatoid arthritis
}

\author{
HANS M. HÖYERAAL \\ Institute of Immunology and Rheumatology, Rikshospitalet and Oslo Sanitetsforening \\ University Hospitals, Oslo 1, Norway
}

Juvenile rheumatoid arthritis (JRA) is thought by many to be a different disease from rheumatoid arthritis in adults (RA), partly because of the infrequency of pathological serological phenomena (Calabro, 1966). Recent investigations have, however, shown that antigammaglobulin and antinuclear antibodies are often found in sera from patients with JRA (Kåss and Munthe, 1969; Torrigiani, Ansell, Chown, and Roitt, 1969; Zutshi, Ansell, Bywaters, Epstein, Holborow, and Reading, 1969; Bianco, Panush, Stillman, and Schur, 1971). It is unknown whether these autoantibodies result from an abnormal antigen stimulation in a normal immunological apparatus or from a normal antigen stimulation in an abnormal immunological apparatus. Scant information is available regarding the possible alteration of cellular immune reactions in patients with JRA (Panush, Bianco, Schur, Rocklin, David, and Stillman, 1972).

The purpose of this investigation was to study the immunological apparatus in patients with JRA. The present report describes the results of testing of delayed hypersensitivity in a group of patients, compared with the results obtained in age- and sexmatched controls.

\section{Materials and methods}

PATIENTS AND CONTROLS

Testing was performed in 34 patients with JRA at the Oslo Sanitetsforening's Hospital for Rheumatic Diseases, Oslo, Norway, and in 34 age- and sex-matched healthy non-hospitalized children during the period September, 1971, to February, 1972. In both groups the mean age was $9 \cdot 1$ yrs (range 2 to 16 ). The age difference in each patient and matched control pair was less than 1 year. The ratio of the number of females to the number of males was 1.8 .

The diagnosis of JRA was based on the criteria of Ansell and Bywaters (1969). 56 per cent of the patients had the polyarticular, 29 per cent. monarticular, and 15 per cent. acute febrile disease type according to the criteria of Calabro and Marchesano (1968). 22 patients were classified as active and twelve as inactive according to the criteria of Ansell and Bywaters (1959). The majority of the patients was classified as belonging to anatomical stage II and functional class II (Steinbrocker, Traeger, and Batterman,
1949). The mean duration of disease was 2.9 yrs (range $0 \cdot 3$ to 12 ). Rheumatoid factor in the serum was found in three patients ( 9 per cent.) by the Waaler-Rose test and in seven patients ( 21 per cent.), by the latex slide test (Hyland, Los Angeles, Calif., U.S.A.), whereas only one male control had a positive latex slide test. Twelve patients (35 per cent.) had antinuclear antibodies in their sera when examined by the indirect immunofluorescence test. Positive tests were significantly $(P<0.02)$ more frequent in female patients $(50$ per cent.) than in male patients $(8$ per cent.). None of these twelve patients had a positive LE test. None of the controls had detectable antinuclear antibodies in their sera. The sex ratio, age-, and type-distribution and frequency of pathological serological phenomena in the present study conform with those in larger clinical materials (Ansell and Bywaters, 1969; Bluestone, Goldberg, Katz, Marchesano, and Calabro, 1970).

Five patients (15 per cent.) had amyloidosis found by Congo red staining and immunofluorescence staining of preparations from liver and/or kidney biopsies. One male patient had hypogammaglobulinaemia with reduced IgG and undetectable IgA. The mean erythrocyte sedimentation rate in the patient and control groups was 44.1 and $5.9 \mathrm{~mm}$. respectively. At testing there was no significant difference between the number of lymphocytes in the peripheral blood in the patient and control groups, 3200 and 3300 cells $/ \mathrm{mm}^{3}$, respectively. During testing 32 patients received one or more of the following drugs: salicylates, hydroxychloroquine, prednisone, gold, and azathioprine. The number of patients on each drug and the dosages given are shown in Table IV.

\section{SKIN TESTING}

All individuals were injected intradermally on the volar aspect of the forearm with $0.1 \mathrm{ml}$. of the following antigens diluted in physiological saline with 0.5 per cent. phenol:

(1) Candida albicans (Dermatophytin ' $O$ ' from Hollister Stier, Yeandon, Penn., U.S.A.) diluted 1:100.

(2) Trichophytin (Dermatophytin from Hollister Stier, Yeandon, Penn., U.S.A.) diluted 1:100.

(3) Streptokinase-streptodornase (Varidase from Lederle, Pearl River, N.Y., U.S.A.) 50 SK units $/ \mathrm{ml}$.

(4) Mumps virus antigen (Mumps skin test antigen from Lilly, Indianapolis, Ind., U.S.A.) undiluted.

(5) Brucella abortus Bang (WHO International Laboratory for Biological Standards, Copenhagen) $2 \cdot 10^{7}$ bacteria/ $\mathrm{ml}$. 
(6) Purified protein derivatives of tuberculin (PPD) from National Veterinary Institute, Oslo) $30 \mathrm{TU} / \mathrm{ml}$.

The antigens given to each pair were from the same batch.

The diameter of both erythema and induration was measured after $4,24,48$, and $72 \mathrm{hrs}$. If the induration at 24 or $48 \mathrm{hrs}$ was less than $5 \mathrm{~mm}$. for the antigens 1, 2, and $3,0 \cdot 1 \mathrm{ml}$. of a higher concentration of these was given intradermally (Fudenberg, Good, Goodman, Hitzig, Kunkel, Roitt, Rosen, Rowe, Seligmann, and Soothill, 1971) namely:

(1) Candida albicans diluted 1:10.

(2) Trichophytin diluted 1:10.

(3) Varidase $400 \mathrm{SK} / \mathrm{ml}$.

Blood was taken from all individuals before testing. All injections and measurements of the reactions were performed by the same person. The healthy controls were tested in their homes after a general medical and haematological investigation. No local or systemic complication was observed in the tested children. Particularly no effect on the activity of the disease was registrated.

To obtain a simple expression of the total reactivity in each individual, the results were also expressed as a combined score. This was defined as the mean of all reactions in an individual, when the result for each antigen was expressed as the percentage of the mean reactivity to that antigen in the control group. For each antigen only the readings at either 24 or $\mathbf{4 8}$ hours were used for analysis. The time selected was that of greatest reactivity to that antigen.

STATISTICS

The Wilcoxon test for pair differences (Diem, 1962) was used when comparing the reactivity to each antigen and the combined score in the patient and the matched control group. When comparing the reactivity in two groups of non-paired individuals, e.g. female and male individuals, the Wilcoxon test for two samples was used. The significance of a correlation between the combined score and age was tested by linear regression analysis.

\section{Results}

The means of the diameters of erythema and induration at the time of greatest reactivity are given in
Table I. For Candida albicans, streptokinase-streptodornase, and PPD, both erythema and induration were greatest after $48 \mathrm{hrs,}$, for mumps virus and Brucella abortus Bang after $24 \mathrm{hrs}$ and for trichophytin after $4 \mathrm{hrs}$. As an example, the reaction pattern to the Brucella antigen is given in Fig. 1. The strongest reactions were obtained with mumps virus and Brucella abortus Bang. Since the reactions to trichophytin were more like an Arthus type and not of the typical delayed type, they were excluded from further analysis.

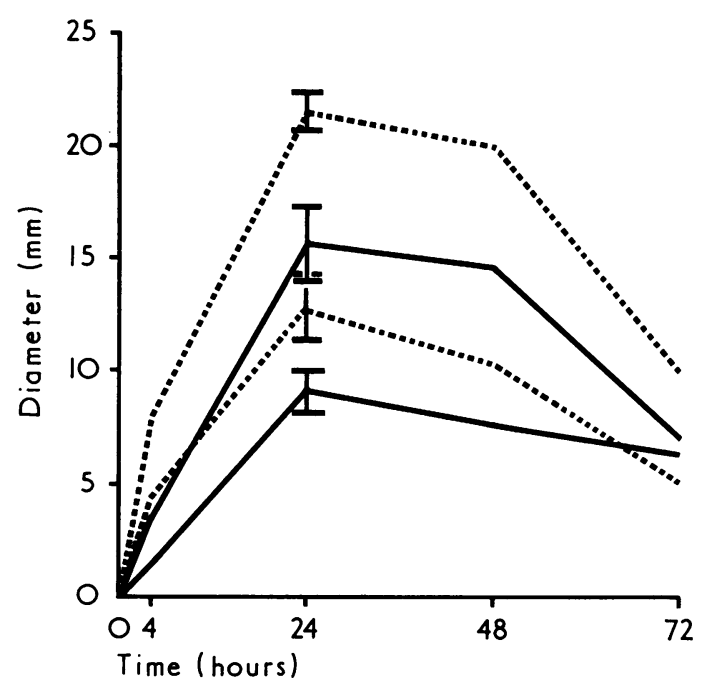

FIG. 1 Relationship between time and reactions to Brucella abortus Bang in fifteen patients with JRA (two lower lines) and in 28 controls (two upper lines). Mean diameters of erythema indicated by dotted lines and of induration by continuous lines. Limits indicate 1 S.E. of means obtained at time of greatest reactivity

Table I Delayed hypersensitivity reactions of the JRA and control groups expressed as mean diameters $(\mathrm{mm}$.) \pm 1 standard deviation for both erythema and induration.

\begin{tabular}{|c|c|c|c|c|c|c|}
\hline \multirow[t]{2}{*}{ Antigen* } & \multirow{2}{*}{$\begin{array}{l}\text { Dilution } \\
\text { or concentration }\end{array}$} & \multirow[t]{2}{*}{ No. } & \multicolumn{2}{|l|}{$J R A$} & \multicolumn{2}{|l|}{ Controls } \\
\hline & & & Erythema & Induration & Erythema & Induration \\
\hline Candida albicans & $\begin{array}{l}1: 100 \\
1: 10\end{array}$ & $\begin{array}{l}29 \\
21\end{array}$ & $\begin{array}{l}6 \cdot 3 \pm 5 \cdot 0 \\
9 \cdot 4 \pm 6 \cdot 3\end{array}$ & $\begin{array}{l}3 \cdot 0 \pm 4 \cdot 3 \\
5 \cdot 3 \pm 4 \cdot 8\end{array}$ & $\begin{array}{r}5 \cdot 5 \pm 3 \cdot 5 \\
13 \cdot 5 \pm 10 \cdot 2\end{array}$ & $\begin{array}{l}2 \cdot 8 \pm 3 \cdot 5 \\
8 \cdot 3 \pm 8 \cdot 1\end{array}$ \\
\hline $\begin{array}{l}\text { Streptokinase and } \\
\text { streptodornase }\end{array}$ & $\begin{array}{l}50 \mathrm{SK} / \mathrm{ml} \text {. } \\
400 \mathrm{SK} / \mathrm{ml} \text {. }\end{array}$ & $\begin{array}{l}34 \\
28\end{array}$ & $\begin{array}{l}4 \cdot 9 \pm 6 \cdot 6 \\
9 \cdot 1 \pm 5 \cdot 4\end{array}$ & $\begin{array}{l}2 \cdot 1 \pm 4 \cdot 0 \\
3 \cdot 5 \pm 5 \cdot 5\end{array}$ & $\begin{array}{r}6 \cdot 3 \pm 9 \cdot 1 \\
10 \cdot 0 \pm 9 \cdot 4\end{array}$ & $\begin{array}{l}2 \cdot 6 \pm 6 \cdot 4 \\
4 \cdot 5 \pm 5 \cdot 5\end{array}$ \\
\hline Mumps virus & Undiluted & 34 & $13 \cdot 7 \pm 7 \cdot 1$ & $9 \cdot 5 \pm 5 \cdot 6$ & $20 \cdot 7 \pm 7 \cdot 7$ & $\overline{16 \cdot 2 \pm 8 \cdot 1}$ \\
\hline Brucella abortus & $2 \cdot 10^{7}$ bact. $/ \mathrm{ml}$. & 34 & $14 \cdot 0 \pm 6 \cdot 6$ & $7 \cdot 7 \pm 4 \cdot 9$ & $21 \cdot 4 \pm 6 \cdot 2$ & $12 \cdot 4 \pm 7 \cdot 1$ \\
\hline Purified protein derivative & $30 \mathrm{TU} / \mathrm{ml}$. & 34 & $2 \cdot 0 \pm 4 \cdot 2$ & $1 \cdot 1 \pm 4 \cdot 0$ & $3 \cdot 8 \pm 7 \cdot 5$ & $2 \cdot 9 \pm 6 \cdot 3$ \\
\hline
\end{tabular}

- All antigens were given in a volume of $0.1 \mathrm{ml}$. The diameters given are for mumps and Brucella 24 hrs and for the others 48 hrs after antigen administration. 
The mean reaction to each of the remaining five antigens was lower in the patients than in the controls (Tables I and II). For Candida albicans, the difference between the reactivity in the patient and the control groups was not statistically significant. Even in male patients, having only half the reactivity of male controls, the difference was not significant. For streptokinase and streptodornase the difference between the reactivity in patients and controls was also not significant, but male patients had significantly lower induration than male controls. The reactivity to mumps virus and Brucella abortus Bang was significantly lower in the patient than in the control group. This was true for both female and male patients. The lower reactivity to PPD in the patient group than in the control group was not significant.

The total reactivity, expressed by the combined score, was significantly lower in the patients than in the controls. In the patient group erythema was 74 per cent. of that in the control group, while that for induration was 67 per cent. There was no differ-

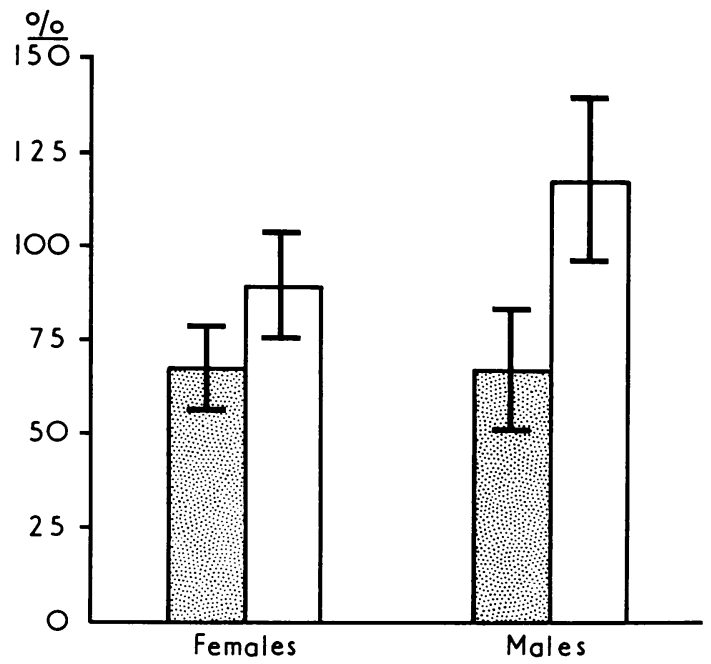

FIG. 2 Combined score for induration in female and male patients (black columns) and controls (white columns). Limits represent 1 S.E. of means ence in the total reactivity between the female and male patients, whereas male controls reacted more strongly than male patients (Fig. 2). Choosing arbitrarily induration $\geqslant 5 \mathrm{~mm}$. at 24 or $48 \mathrm{hrs}$ as the limit for a positive reaction, the mean number of positive reactions for the five antigens was 2.9 and 3.3 in the patient and the control groups, respectively. This difference was statistically not significant.

Several factors were tested for their possible influence on the total reactivity, expressed by the combined score. Apart from the sex differences mentioned above, the reactivity was found to vary with age, the number of lymphocytes in the peripheral blood, and the grade of functional capacity. The reactivity increased with increasing age (Fig. 3, overleaf).

A negative correlation was found between the combined score and the number of lymphocytes in the peripheral blood (Table III, overleaf). Ten children with lymphocyte counts $\geqslant 5000 / \mathrm{mm}^{3}$ had lower reactivity than those with lymphocyte counts $<5000 / \mathrm{mm}^{3}$. This difference was statistically significant for the control group, but not for the patient group. The six patients in functional capacity classes III and IV showed significantly lower reactivity than their age- and sexmatched control pairs.

No significant correlation between the reactivity and the following factors was found: Duration of disease, erythrocyte sedimentation rate, albumin/ globulin ratio, and albumin/gammaglobulin ratio. Neither was there any definite relationship between reactivity and general nutritional and health state expressed by length and weight percentiles, presence or absence of rheumatoid factor, antinuclear antibodies, amyloidosis, or treatment with salicylates, antimalarial drugs, gold, prednisone, or azathioprine (Table IV, overleaf), or types or anatomical stages of JRA.

\section{Discussion}

Delayed hypersensitivity was statistically significantly lower in a group of patients with JRA than in a healthy control group. Similar observations have been made in adults with RA (Hayes, Ward, and Jennings,

Table II Mean reactivity in patients with JRA expressed in per cent. of that in their respective control groups

\begin{tabular}{|c|c|c|c|c|c|c|}
\hline \multirow[t]{2}{*}{ Antigen } & \multicolumn{2}{|c|}{ All patients } & \multicolumn{2}{|c|}{ Females (22) } & \multicolumn{2}{|l|}{ Males (12) } \\
\hline & Erythema & Induration & Erythema & Induration & Erythema & Induration \\
\hline $\begin{array}{l}\text { Candida albicans* } \\
\text { Streptokinase*-streptodornase } \\
\text { Mumps virus } \\
\text { Brucella abortus } \\
\text { Purified protein derivative }\end{array}$ & $\begin{array}{l}81 \\
82 \\
66 \pm \\
66 \$ \\
52\end{array}$ & $\begin{array}{l}76 \\
72 \\
58 \ddagger \\
62 \ddagger \\
38\end{array}$ & $\begin{array}{l}98 \\
89 \\
67 \ddagger \\
66 \ddagger \\
53\end{array}$ & $\begin{array}{l}97 \\
87 \\
68 \dagger \\
66 \\
12\end{array}$ & $\begin{array}{l}58 \\
64 \\
64 \\
65 \dagger \\
51\end{array}$ & $\begin{array}{l}46 \\
34 \\
42 \dagger \\
56 \ddagger \\
51\end{array}$ \\
\hline Combined score & $74 \dagger$ & $67 \dagger$ & 77 & 75 & 69 & 57 \\
\hline
\end{tabular}

* The reactivity given was based on the highest dose of antigen given to both members comprising a patient and control pair.

$\dagger=\mathrm{P}<0.05 . \quad \ddagger=\mathrm{P}<0.01$. $\$=\mathrm{P}<0.001$. 
Table III Relationship between mean combined score and number of lymphocytes in peripheral blood

\begin{tabular}{|c|c|c|c|c|c|c|}
\hline \multirow{2}{*}{$\begin{array}{l}\text { Lymphocytes } \\
\text { per mm. }\end{array}$} & \multicolumn{3}{|c|}{ Patients* } & \multicolumn{3}{|c|}{ Controls } \\
\hline & No. & Erythema & Induration & No. & Erythema & Induration \\
\hline$\geqslant 5,000$ & 5 & 64) & \multirow{2}{*}{$\left.{ }_{77}^{47}\right\} \mathrm{NS}$} & 5 & 44 & $37)$ \\
\hline$<5,000$ & 25 & NS & & 29 & $110\}^{\prime}$ & $111\}^{\prime}$ \\
\hline
\end{tabular}

- Differential counts were not available from four patients at the time of testing.

NS $=$ Not significant. $\dagger=P<0.01$.

Table IV Relationship between medication and reactivity

\begin{tabular}{|c|c|c|c|}
\hline Medication & $\begin{array}{l}\text { Average dose } \\
\text { (mg./day) }\end{array}$ & $\begin{array}{l}\text { No. of } \\
\text { patients }\end{array}$ & $\begin{array}{l}\text { Combined score for induration as } \\
\text { percentage of that of respective } \\
\text { age- and sex-matched controls }\end{array}$ \\
\hline Salicylates & $\begin{array}{l}58 / \mathrm{kg} . \\
0\end{array}$ & $\begin{array}{r}27 \\
7\end{array}$ & $\begin{array}{l}79 \\
34\end{array}$ \\
\hline Hydroxychloroquine & $\begin{array}{c}200 \\
0\end{array}$ & $\begin{array}{l}13 \\
21\end{array}$ & $\begin{array}{l}67 \\
67\end{array}$ \\
\hline Prednisone & $\begin{array}{c}7.4 \\
0\end{array}$ & $\begin{array}{l}10 \\
24\end{array}$ & $\begin{array}{l}91 \\
61\end{array}$ \\
\hline Gold & $\begin{array}{c}200^{*} \\
0\end{array}$ & $\begin{array}{r}5 \\
29\end{array}$ & $\begin{array}{r}104 \\
62\end{array}$ \\
\hline Azathioprine & $\begin{array}{r}50 \\
0\end{array}$ & $\begin{array}{r}3 \\
31\end{array}$ & $\begin{array}{l}66 \\
67\end{array}$ \\
\hline
\end{tabular}

* Accumulated dose.

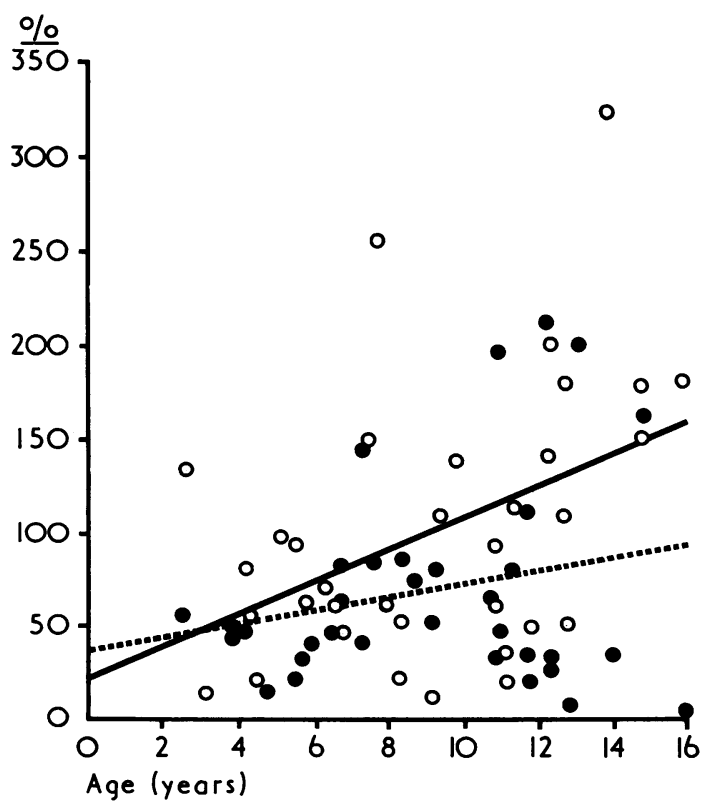

FIG. 3 Correlation between reactivity (combined score for induration) and age in 34 patients with JRA and their controls. Individual values are shown by closed circles (patients) and open circles (controls). Regression lines are for patient group (dotted) and for control group (continuous). Increase in reactivity with increasing age significant for controls $(\mathrm{b}=8.7 ; P<0.01)$, but not for patients $(\mathrm{b}=3.4 ; P>0.05)$.
1970; Whaley, Glen, MacSween, Deodhar, Dick, ڤొ Nuki, Williamson, and Buchanan, 1971), but to my尺 knowledge not in patients with JRA.

To obtain a semiquantitative method, a panel of 3 antigens from bacteria, virus, and fungi was used and, at least for two of the antigens, in differento dosages. A higher sensitivity than merely recording negative or positive reactions based on an arbitrarilyo chosen limit, was obtained by expressing the measured reactivity of the patients as a percentage of that of the controls. The variation in the results was relativelyo high. For most of the antigens completely negative reactions could be observed in both patients and? controls.

The reactivity in vivo was found to vary with age, sex, number of lymphocytes in the peripheral blood, N and functional capacity. The reactivity increased with increasing age. The difference in reactivity between 0 patients and controls was generally greater in males $N$ than in females. This is in accordance with the find- 0 ings of Hayes and others (1970) studying adults witho RA. Age- and sex-differences should not influence the results in the present investigation as the reactivity in? pairs of individuals with the same age and sex was? compared.

The negative correlation between the reactivity and the number of lymphocytes was somewhat un- $-\stackrel{\mathbb{Q}}{\Omega}$ expected, but was consistent with observations byo Panush and others (1972). Possibly the number in the peripheral blood may not represent the number of 
reactive cells available for delayed hypersensitivity reactions in the skin. No definite infection was detected in the ten children with lymphocyte counts $\geqslant 5000 / \mathrm{mm}^{3}$ and their mean erythrocyte sedimentation rate was below the mean for their respective groups.

There is probably no good parameter of disease activity in JRA. Therefore several clinical and laboratory parameters were tested for a possible relationship with delayed hypersensitivity. No definite relationship was found, apart from a more pronounced impairment of reactivity in the patients with low functional capacity.

Poor general health, especially starvation and malnutrition, can impair delayed hypersensitivity (Hayes and others, 1970; Geefhuysen, Rosen, Katz, Ipp, and Metz, 1971). In the present study all individuals received adequate nutrition. Five of the patients, but none of the controls, were below the 2.5 percentile (length for age). However, their reactivity was not significantly lower than that of those with normal lengths for their ages.

It may be argued that the lower reactivity in the patient group could be due to drugs. When the reactivity in those patients receiving and those not receiving a certain drug was compared, there was no evidence for this. This conforms with the findings by Hayes and others (1970) for prednisone in patients with RA and the findings by Denman, Denman, Greenwood, Gall, and Heath (1970) that prednisone, chlorambucil, and azathioprine failed to suppress cellular immune reactions both in vivo and in vitro in patients with RA and JRA.

It has been suggested that individuals with low reactivity when testing for pre-existing delayed hypersensitivity, may be further evaluated by active sensitization with 2:4 dinitrochlorobenzene (DNCB) (Fudenberg and others, 1971). Since DNCB may give unpleasant burn reactions, and subsequent testing may be difficult to interpret and is not positive in all healthy individuals (Turk, 1969), only three patients with low reactivity have been tested. They all showed evidence of sensitization (Höyeraal, unpublished results).

Panush and others (1972) found a dissociation of manifestations in vivo and in vitro of cellular immune reactions in half of a group of patients with JRA. A similar dissociation, significantly reduced activity by in vivo testing, but not by in vitro testing, of cellular immune reactions, has recently been reported in patients with systemic lupus erythematosus by Horwitz (1972). Three patients with low combined score in the present study were therefore also tested by in vitro studies of lymphocyte reactivity (Höyeraal and Fröland, unpublished results). Their lymphocytes responded normally to the unspecific mitogens phytohaemagglutinin, pokeweed mitogen, and concanavaline $\mathbf{A}$, and on allogenic lymphocytes in the one- way mixed lymphocyte culture. Our results seem to be consistent with these findings.

The present results may indicate an impairment of delayed hypersensitivity in JRA. This could result from a T-lymphocyte defect. However, the DNCB sensitization and the in vitro experiments which indicated a normal $T$-cell reactivity might rather suggest a macrophage defect or a defect in the lymphokines or other mediators of inflammation. Theoretically, the reduced reactivity might be due to local factors in the skin. In the present study the skin appeared to be normal in all the individuals.

Defects in the humoral immunity may also occur in patients with JRA (Good, Rötstein, and Mazzitello, 1957). Selective immunoglobulin deficiency of IgA is about ten times more frequent in patients with JRA than in healthy controls (Panush and others, 1972). Measurements of humoral immunity in the patients and controls studied in the present report are in progress.

If an impairment of the immunological apparatus in patients with JRA exists, this could explain the increased tendency to infections by a variety of organisms experienced by rheumatoid patients (Huskisson and Hart, 1972). It could also indicate that further studies need to focus on the immunological apparatus in these patients in addition to look for possible causing antigens. Such studies may help to clarify the pathogenesis of the disease and give guidance to the vaccination policy and possible rational forms of treatment of these patients.

\section{Summary}

By in vivo testing using a panel of antigens, the delayed hypersensitivity in $\mathbf{3 4}$ patients with JRA was found to be significantly lower than in a healthy age- and sex-matched control group. The reactivity increased with increasing age, and was mainly impaired in male patients and in patients with low functional capacity. It also seemed to vary inversely with the number of lymphocytes in the peripheral blood. None of several other clinical or laboratory factors were found to have a definite relationship with the reactivity. The impaired reactivity could result from a $T$-lymphocyte defect, but also from a macrophage defect or a defect in the lymphokines or other mediators of inflammation.

This work was supported by The Norwegian Council for Science and The Humanities and The Norwegian Women's Public Health Organization.

I am grateful to Dr. P. Blichfeldt for help with the clinical evaluation of the patients and to Prof. K. Westlund for guidance with the statistical analysis of the results. Dr. S. S. Fröland, Dr. O. J. Mellbye, and Dr. J. B. Natvig have shown great interest in this study and given valuable suggestions. 


\section{References}

ANSELl, B. M., AND Bywaters, E. G. L. (1969) 'Juvenile chronic polyarthritis or Still's disease' in 'Textbook of the Rheumatic Diseases', ed. W. S. C. Copeman, 4th ed., p. 323. Livingstone, Edinburgh

- (1959) Bull. rheum. Dis., 9, 189 (Prognosis in Still's disease)

Bianco, N. E., Panush, R. S., Stillman, J. S., AND Schur, P. H. (1971) Arthr. and Rheum., 14, 685 (Immunologic studies of juvenile rheumatoid arthritis)

Bluestone, R., Goldberg, L. S., Katz, R. M., Marchesano, J. M., and Calabro, J. J. (1970) J. Pediat., 77, 98 (Juvenile rheumatoid arthritis: A serologic survey of 200 consecutive patients)

Calabro, J. J. (1966) 'Juvenile rheumatoid arthritis' in 'Arthritis and Allied Conditions', ed. J. L. Hollander, 7th ed., p. 220. Lea and Febiger, Philadelphia

— AND MARChESANo, J. M. (1968) Med. Clin. N. Amer., 52, 567 (The early natural history of juvenile rheumatoid arthritis. A 10-year follow-up study of 100 cases)

Denman, E. J., Denman, A. M., Greenwood, B. M., Gall, D., And Heath, R. B. (1970) Ann. rheum. Dis., 29, 220 (Failure of cytotoxic drugs to suppress immune responses of patients with rheumatoid arthritis)

DIEM, K. (ed.) (1962) 'Documenta Geigy. Scientific Tables', 6th ed. Geigy, Manchester

Fudenberg, H., Good, R. A., Goodman, H. C., Hitzig, W., Kunkel, H. G. (Chairman), Roitt, I. M., Rosen, F. S., Rowe, D. S., Seligmann, M., AND Soothill, J. R. (1971) Pediatrics, 47, 927 (Primary immunodeficiencies. Report of a World Health Organization Committee)

GeefHuYsen, J., Rosen, E. U., KATZ, J., IPP, T., AND MetZ, J. (1971) Brit. med. J., 4, 527 (Impaired cellular immunity in kwashiorkor with improvement after therapy)

Good, R. A., RöTstein, J., AND MAzzitello, W. F. (1957) J. Lab. clin. Med., 49, 343 (The simultaneous occurrence of rheumatoid arthritis and agammaglobulinemia)

HAYES, J. R., WARD, D. J., AND JENNINGS, J. F. (1970) 'Studies on cell-mediated hypersensitivity responses in rheumatoid arthritis' in 'Proceedings of the Third Symposium. Impaired Cell-Mediated Hypersensitivity in Man. Clinical and Immunological Aspects', ed. J. F. Jennings and D. J. Ward, p. 37, The Robert Jones and Agnes Hunt Orthopaedic Hospital Management Committee, Oswestry

HoRWITZ, D. A. (1972) Arthr. and Rheum., 15, 353 (Impaired delayed hypersensitivity in systemic lupus erythematosus)

Huskisson, E. C., AND HART, F. D. (1972) Ann. rheum. Dis., 31, 118 (Severe, unusual, and recurrent infections in rheumatoid arthritis)

KÅss, E., AND MUNTHE, E. (1969) 'Anti- $\gamma$-globulin and anti-nuclear antibodies in juvenile rheumatoid arthritis' in 'Abstracta. XII. Congressus Rheumatologicus Internationalis, Praga', Abstr. no. 666. Geigy, Basle

Panush, R. S., Bianco, N. E., Schur, P. H., Rocklin, R. E., David, J. R., and Stillman, J. S. (1972) Clin. exp. Immunol., $\stackrel{\mathbb{Q}}{\mathscr{Q}}$ 10, 103 (Juvenile rheumatoid arthritis. Cellular hypersensitivity and selective IgA deficiency)

Steinbrocker, O., Traeger, C. H., and Batterman, R. C. (1949) J. Amer. med. Ass., 140, 659 (Therapeutic criteria in rheumatoid arthritis)

Torrigiani, G., Ansell, B. M., Chown, E. E. A., ANd Roitt, I. M. (1969) Ann. rheum. Dis., 28, 424 (Raised IgG antiglobulin factors in Still's disease)

TURK, J. L. (1969) Bull. Wld Hlth Org., 41, 779 (Cell-mediated immunological processes in leprosy)

Whaley, K., Glen, A. C. A., MacSween, R. N. M., Deodhar, S., Dick, W. C., Nuki, G., Williamson, J., AND BUCHANAN, W. W. (1971) Clin. exp. Immunol., 9, 721 (Immunological responses in Sjögren's syndrome and rheumatoid arthritis)

Zutshi, D. W., Ansell, B. M., Bywaters, E. G. L., Epstein, W. V., Holborow, E. J., ANd Reading, C. A. (1969) Ann. rheum. Dis., 28, 541 (FII haemagglutination test for serum antigammaglobulin factors in Still's disease) 